\title{
Entertainment in Jordanian Malls
}

\author{
Salem Ahmad Alrhaimi ${ }^{1} \&$ Thair Habboush ${ }^{2}$ \\ ${ }^{1}$ College of Administrative and Financial Sciences, Irbid National University, Jordan \\ ${ }^{2}$ College of Business, University of Jeddah, Saudi Arabia \\ Correspondence: Salem Ahmad Alrhaimi, College of Administrative and Financial Sciences, Irbid National \\ University, Jordan. E-mail: salemalrahimy@gmail.com
}

Received: May 1, 2015

Accepted: May 21, 2015

Online Published: June 25, 2015

doi:10.5539/ibr.v8n7p78

URL: http://dx.doi.org/10.5539/ibr.v8n7p78

\begin{abstract}
Modern lifestyle is hard to imagine without the hustle and bustle that takes place in shopping malls that have become part and parcel of the economic and social life of every modern global citizen. Shopping malls are on the increase in major cities with Jordan being a hub for competitors in the mall industry. Hence, there is a growing need to understand consumers' perceptions, dispositions and preferences as to the mall image nowadays. The purpose of this research is to determine the effect and significance of entertainment on the mall industry in Jordan. The data were conducted by structured questionnaire from 450 shoppers who visit the five largest malls, namely, AL-Mukhtar, Sameh, Arabella, Irbid, and AL-Safeway in Irbid as the biggest and high density city in the north territory of Jordan. The results of study showed that the age group less than 25 years of shoppers ranked first in patronage of the shopping malls mainly for reasons related to leisure, fun and entertainment. The study concludes by emphasizing the need for huge entertainment facilities, such as, family entertainment centers, cinema, gym, bowling alley, billiard hall and video games.
\end{abstract}

Keywords: shopping malls, entertainment, marketing, Jordan

\section{Introduction}

Quite recently, some countries in Asia have come to the fore as a result of economic success and prosperity that took place in many fields. Accordingly, new changes affected the direction of the economy in those countries. One specific aspect that manifested itself in the economy has been the culture of shopping at malls with many people frequenting such places. Arab countries as well have had their share of such economic boom with an emphasis on building shopping centers of different shapes and sizes to attract shoppers and develop this new business trend. Dubai, for instance, is considering a plan to erect what might be one of the largest malls in the world as it intends to set up about nine million square foot shopping center in 2007 (Andersen, 2003, 2005).

World business nowadays seems to have shifted to meet the demands of a new life style in big cities where shopping at malls have affected both lives of the rich and the poor. Thus, such malls have begun to be frequented by different classes of the society and not only by the upper classes. Less than one single roof, all that one desires of goods and services can be obtained without much effort. In addition to shopping such milestones have become the best places to be in order to socialize with others (Anuradha \& Manohar, 2011).

In the past few years Jordan witnessed a boom in the mall business which is attested by building a good number of large malls in the major Jordanian cities. This has started a new shopping trend for Jordanians who have started to frequent such malls which offer a variety of goods and services to satisfy different needs. Hence, there is a necessity to study shoppers' behavior when they visit such malls and give feedback for mall planners and business people to develop their services through specifying what might affect shoppers' behaviour (Al-Khateeb, 2009) Malls have a tangible role to play in shoppers' way of life (Terblanche, 1999). As far as purposes are concerned, shopping malls tend to satisfy many goals. Ng (2003) holds, apart from shopping malls being shopping centers, they are community centers where socialization and entertainment take place. In addition to the products offered, malls provide a wide range of services including banking, entertainment, food, cinemas, playing areas for children, and promotional areas etc. (Terblanche, 1999).

Studies that addressed shoppers' patterns of behavior at the malls in the Arab Middle East are not comprehensive. In one of these studies, El-Adly (2001) pointed out main factors that affected the style that has distinguished the UAE shoppers. These comprise ethnic mix, lifestyle, cultural differences, humidity, hot weather and economic 
prosperity.

Thanks to the large number of shopping malls, shoppers are more spoiled for choice and they are possibly inclined to visit malls that are stylish and offer various goods and services that appeal to their tastes. Hence, it is now essential for mall managers to have a clear idea about how appealing their malls are to their customers (Wong et al., 2001). Yet, mall attributes that appeal to some shoppers may not be appealing for others (Al Edly, 2007). As researchers admit, not many studies were done to tackle motivational behaviour that stimulates shoppers to patronise malls (Bodkin \& Lord, 1997; Ruiz, 1999; Dennis et al., 2001; Nicholls et al., 2000, 2002).

As retailing has developed, competition grew fierce among malls that cropped up everywhere in urban areas. This made shoppers be more selective in choosing to patronize malls that are more attractive and offer a wide variety of goods and services that appeal to their preferences (El-Adly, 2007). Accordingly, it is of paramount importance for mall managers to know how much their malls are attractive to their shoppers (Wong et al., 2001). However, mall attributes that are attractive for some shoppers are not necessarily attractive for others. With that in mind, this paper seeks to determine the effect and importance of entertainment on the Jordanian malls.

\section{Research Objectives}

The goal of this study is to identify the significance of entertainment on the mall industry in Jordan, and to establish whether there is a need to take care of entertainment as an aspect that affects mall shoppers and the mall industry as a whole.

\section{Literature Review}

\subsection{Entertainment}

In our modern world, shopping malls are a witness to a new lifestyle that many people are living. Indeed, shopping malls have affected small businesses as they are huge buildings that provide a huge volume of goods and services.

The concept of the mall itself has drastically changed with entertainment being crucial and indispensable to shopping practices. Malls have become places where entertainment and social excitement are part of the shopping phenomena at the mall (Frat \& Venkalesh, 1993; Pine \& Gilmore, 1999).

Though entertainment as an activity is widespread, not enough research can be found on this aspect (Parsons, 2003; Sit et al., 2003). This dimension has evolved into a new global concept (Groover, 2005). For the purpose of appealing to the different tastes of consumers, malls shifted attention to entertainment. Many recreational activities and facilities are now essential to the mall concept such as restaurants, food courts, video arcades, movie theatres, beauty salons, dental offices, and more. Malls in addition have provided a venue for a meeting for both young and old people. Mall managers have taken advantage of this trend and have started making room for art exhibits, health screening, auto shows, and live music. Malls have now shifted to be huge entertainment centers, dwarfing the business of other retail shoppers (Ahmed et al., 2007).

Based on its lexical meaning, entertainment is connected with joy and interest. Despite the existence of rather little research on entertainment, this dimension has emerged as crucial in the mall industry. Researchers believe that if entertainment is observed, it will benefit their planning and develop their knowledge on pleasurable aspects of shopping centers (Sit et al., 2003).

Underhill (1999) draws attention to the discrepancy as to being uncertain if one is in a mall or a theme park. Thus, it is now difficult to distinguish shopping as separate from entertainment as to go to the mall has crossed the line of purchasing goods to the simple idea of seeking fun and pleasure (Smith, 2003).

A late study maintains that shopping Centre entertainment is a novel idea across the world occupying a major segment in shopping activities (Groover, 2005). One view of shopping has now incorporated pleasure and entertainment. Thus, shopping centers do not only function to meet the consumer basic needs requirements but also aim to satisfy other needs including entertainment and hedonic aspects (Pride \& Ferrell, 1983). Previous research on consumer choice in shopping Centre also focus on social aspects and values including entertainment and comfort that play a big role in the consumers' decision-making (Michon \& Chebat, 2004).

Shoppers' motivation means different things as regards hedonic or utilitarian concerns. Those interested in utilitarianism hold that "shopping is a form of work". Others are engaged in hedonism aspects and they focus on enjoyment, excitement, experiences that stem from shopping activities (Nicholls et al., 2002; Kim et al., 2003).

In a study by Taylor and Cosenza (2002) the shopping choice behavior of a considerable segment of teen market called, "Later aged female teen" was examined. The results showed that typical later aged female teen were right in their choices especially for clothing products key points that were emphasized involved the mall's design and 
creating an environment of excitement that aroused the teens to stay longer. In particular, recreation had the biggest role in stimulating shoppers to visit the malls.

With the new arising needs of consumers, malls took new roles to satisfy their various needs. Accordingly, and food facilities became aspects of the new mall idea. It has now become common to find restaurants, theatres, cinemas, sport centers. People with high income can now visit life style centers in their areas of residence to enjoy such services (Levy \& Weitz, 2004, p. 224).

Quite related to entertainment is the notion of convenience. In a comparative study by Reimers and Clulow (2004) on spatial convenience in shopping strips and shopping centers, they emphasized the need for malls to spatial convenience that affects consumers' decisions on their shopping centers.

Entertainment at shopping centers is various in terms of events that take place seasonally, temporarily or intermittently. They are called (SEE) special events entertainment (Sit, Merrilees, \& Birch, 2003). With SEE in mind, managers aim to give reason for shoppers to stay longer and visit more often (Kim, Christiansen, Feinberg, $\&$ Choi, 2005). This will create chances for retailers to benefit from customers who may eat at a restaurant or do unplanned shopping (Parsons, 2003).

Haytko and Baker (2004) explored French female teens behavior in shopping malls where five features seemed to have an impact on their shopping experience. These included comfort, safety, retail mix, accessibility and atmosphere. In a comparative study, Michon and Jean (2004) found that the French are less likely than English shoppers to use the mall for other activities than buying goods and services.

Other studies (Finn \& Louviere, 1996; Sit et al., 2003) emphasized 'image' as a decisive factor as to decisionmaking on mall patronage. Frasquest et al. (2001) signaled out two entertainment elements namely "events, exhibitions, and attractive leisure offer", to be linked to "atmosphere/leisure" attribute. Entertainment could be explained differently as whether it is an additional service or part and parcel of the service. As consumers themselves have various perspectives, a service item might be considered differently as to its meaning and importance.

Bellenger et al. (1977) differentiated two types of shoppers. Recreation-oriented shoppers valued variety and related services of convenience with disregard for saving on price. On the other hand, economic shoppers' value prices more while paying little or no attention to variety and convenience.

Hunter (2006) pointed out that emotional factors including motivation and intention are connected to the shopping Centre image and how often someone visits that center. Sit et al. (2003) came with four attributes that affect such image: merchandising, accessibility, services, and atmospherics. Additionally, three missing features were pointed out as neglected namely (entertainment, food, and security).

Few studies handled entertainment as a separate feature and found it to differ from one environment to another. For example, having a movie theatre is associated with an attribute labelled "presence of related services" (Bellenger et al., 1977). In one of his studies, Sheth (1983) pinpointed three antecedents for shopping preference among a set of alternatives: shopping motives, shopping options; and choice calculus. These three elements lay foundation for a consumer's shopping predisposition (LeHew et al., 2002).

\section{Methodology of the Study}

The population of this study includes all Jordanian shoppers who visit the largest malls in Irbid city, because it has the biggest number of shopping activities and high density of population at the north of Jordan. The study employed non probability sampling in the of 450 shoppers who visit the five largest malls, namely, Irbid Mall, AL-Mukhtar Mall, Sameh Mall, Arabella Mall, and AL-Safeway during June-July 2014. A closed-ended questionnaire was used for the purpose of data collection.

The shoppers' responses were collected on a 5-pionts Likert scale (1: strongly disagree; 5: strongly agree). Through the first part of questionnaire the demographic details of the participants as gender, age, education level, occupations, monthly income, and weekly expenditures in the malls were collected. The validity of questionnaire was conducted through experts' consultations and verifications, while the reliability was tested through Cronbach Alpha by value 0.81 coefficient for all entertainment items. This value is sufficient to determine the reliability of the constructs (Sekaran, 2013).

The analysis of data was carried out using statistical package of social sciences (SPSS) 17 version of Windows. Frequencies, ratios, means and standard deviation as descriptive methods; and multi-variance analysis (MANOVA) and Scheffe test as analytical methods were used to describe the shoppers' characteristics and answer the study question. 


\section{Data Analysis}

\subsection{Profile of the Shoppers}

Demographic profile of the respondents is summarized in Table 1.

Table 1. Shoppers' characteristics

\begin{tabular}{|c|c|c|c|}
\hline Variables & Levels & Frequencies & Percentages $(\%)$ \\
\hline \multirow{2}{*}{ Gender } & Male & 211 & 46.89 \\
\hline & Female & 239 & 53.11 \\
\hline \multirow{6}{*}{$\begin{array}{l}\text { Age group } \\
\text { (year) }\end{array}$} & Less than 25 & 135 & 30.02 \\
\hline & $25-35$ & 104 & 23.11 \\
\hline & $36-45$ & 121 & 26.89 \\
\hline & $46-55$ & 61 & 13.56 \\
\hline & More than 56 & 24 & 6.44 \\
\hline & Single & 199 & 44.22 \\
\hline \multirow{3}{*}{ Marital Status } & Married & 232 & 51.56 \\
\hline & Divorced & 12 & 02.67 \\
\hline & widow & 7 & 01.55 \\
\hline \multirow{5}{*}{ Household Size } & $1-2$ & 57 & 12.67 \\
\hline & $3-4$ & 121 & 26.89 \\
\hline & $5-6$ & 161 & 35.78 \\
\hline & $7-8$ & 78 & 17.33 \\
\hline & More than 9 & 33 & 07.33 \\
\hline \multirow{5}{*}{ Education Level } & Secondary School and below & 129 & 28.66 \\
\hline & Diploma & 140 & 31.11 \\
\hline & Bachelor & 152 & 38.77 \\
\hline & Master & 19 & 04.22 \\
\hline & $\mathrm{PhD}$ & 10 & 02.22 \\
\hline \multirow{4}{*}{ Occupations } & Own business & 64 & 14.22 \\
\hline & Private & 216 & 48.00 \\
\hline & Government & 134 & 29.78 \\
\hline & Others & 36 & 08.00 \\
\hline \multirow{5}{*}{$\begin{array}{l}\text { Gross Monthly } \\
\text { Household Income }\end{array}$} & Less than JD 400 & 53 & 11.78 \\
\hline & JD $400-800$ & 176 & 39.11 \\
\hline & JD $801-1200$ & 92 & 20.44 \\
\hline & JD $1201-1600$ & 67 & 14.89 \\
\hline & more than JD1200 & 62 & 13.78 \\
\hline \multirow{4}{*}{$\begin{array}{l}\text { Weekly Expenditure } \\
\text { in the Malls }\end{array}$} & Less than JD 50 & 260 & 57.78 \\
\hline & JD 50 - 100 & 134 & 29.78 \\
\hline & JD101-150 & 38 & 08.44 \\
\hline & more than JD 150 & 18 & 04.00 \\
\hline \multicolumn{2}{|r|}{ Total } & 450 & $100.00 \%$ \\
\hline
\end{tabular}




\subsection{Entertainment at Jordanian Malls}

Descriptive statistics (means and standard deviations) of the shoppers' entertainment in the Jordanian malls were computed as shown in Table 2.

Table 2. Means and standard deviations of the shoppers' entertainment

\begin{tabular}{clcc}
\hline No. & Items & Mean & S.D \\
\hline 1 & Excitement of entertainment activities makes me stay longer & 4.21 & 0.89 \\
2 & Entertainment activities encourage me to repeat a mall shopping & 4.08 & 0.91 \\
3 & During shopping I prefer a youth areas as cinema, gym, and the like & 4.04 & 0.92 \\
4 & Doing a shopping is one of my enjoyable activities & 4.01 & 0.94 \\
5 & I do a shopping to visit space for kids & 3.82 & 1.21 \\
6 & I do a shopping to break the routine of my life & 3.66 & 1.17 \\
7 & Malls are a good place to eliminate work stress and boring & 3.47 & 1.18 \\
\hline & Total Domain & 3.90 & 0.74 \\
\hline
\end{tabular}

Table 2 shows that means range between (3.47-4.21), being the mean of item number 1 "Excitement of entertainment activities makes me stay longer" ranked firstly with mean (4.21) and standard deviation (0.89), item number 2 "Entertainment activities encourage me to repeat a mall shopping" ranked secondly with mean (4.08) standard deviation (0.91), item number 7 "Malls are a good place to eliminate work stress and boring" ranked finally with mean (3.47) standard deviation (1.13). The whole attractions mean perceived by the shoppers was (3.90) standard deviation (0.74).

\subsection{Study Question}

Are there any significant differences among the shoppers' responses about the entertainment factor in the Jordanian malls due to the shoppers' characteristics?

The researcher computed descriptive statistics (Means, Standard Deviations) for the subjects' responses about the entertainment factor in the Jordanian malls according to the shoppers' characteristics; the results were shown in Table 3.

Table 3. Results of MANOVA-test

\begin{tabular}{cccccc}
\hline Source of Variance & Sum of Squares & df & Mean Square & F & Sig. \\
\hline Gender & 1.792 & 1 & 1.792 & 1.404 & 0.291 \\
Age & 9.120 & 4 & 2.123 & 1.164 & 0.174 \\
Marital Status & 11.696 & 3 & 4.731 & 3.072 & $0.017^{*}$ \\
Household size & 10.001 & 4 & 3.063 & 1.758 & 0.188 \\
Education level & 31.014 & 4 & 7.198 & 4.913 & $0.001^{*}$ \\
Occupation & 7.465 & 3 & 2.581 & 1.702 & 0.156 \\
Gross monthly income & 8.364 & 4 & 2.065 & 1.638 & 0.257 \\
Weekly expenditure & 79.913 & 3 & 28.101 & 17.918 & $0.000^{*}$ \\
Error & 658.097 & 443 & 1.627 & & \\
Corrected Total & 839.612 & 449 & & & \\
\hline
\end{tabular}

Note. * Significant at $(\propto=0.05)$.

Table 3 shows that:

1) There are no significant differences among the means on the entertainment according to the subjects' gender, age, household size, occupation and gross monthly income. 
2) There are significant differences among the means on the entertainment of shoppers in the Jordanian malls according to their marital status, education level and weekly expenditure. To determine the sources of these differences, Scheffe' test was used as shown in Tables (4), (5) and (6).

Table 4. Scheffe' test results (marital status)

\begin{tabular}{cccccc}
\hline Marital Status & & Single & Married & Divorced & widow \\
\hline & Means & 3.98 & 3.87 & 4.41 & 4.56 \\
Single & 3.98 & & & \\
Married & 3.87 & 0.02 & & \\
Divorced & 4.41 & $0.54^{*}$ & $0.57^{*}$ & & \\
widow & 4.56 & $0.59^{*}$ & $0.61^{*}$ & 0.05 & \\
\hline
\end{tabular}

Note. * Significant at $(\propto=0.05)$.

Table 4 shows that there are significant differences between the means of (divorced and widow) and (single and married) in favor of (single and married).

Table 5. Scheffe' test results (education level)

\begin{tabular}{|c|c|c|c|c|c|c|}
\hline \multicolumn{2}{|c|}{ Consumers' education level } & \multirow{2}{*}{$\frac{\text { Secondary }}{3.94}$} & \multirow{2}{*}{$\begin{array}{c}\text { Diploma } \\
3.91\end{array}$} & \multirow{2}{*}{$\frac{\mathrm{BA}}{3.87}$} & \multirow{2}{*}{$\frac{\text { Master }}{4.35}$} & \multirow{2}{*}{$\frac{\mathrm{PhD}}{4.46}$} \\
\hline & Means & & & & & \\
\hline Secondary School and below & 3.94 & & & & & \\
\hline Diploma & 3.91 & 0.01 & & & & \\
\hline Bachelor & 3.87 & 0.03 & 0.01 & & & \\
\hline Master & 4.35 & $0.46^{*}$ & $0.49 *$ & $0.51^{*}$ & & \\
\hline $\mathrm{PhD}$ & 4.46 & $0.52^{*}$ & $0.54 *$ & $0.55^{*}$ & 0.05 & \\
\hline
\end{tabular}

Note. * Significant at $(\propto=0.05)$.

Table 5 shows, that there are significant differences between the means of (Secondary School and below, Diploma and BA) consumers' education levels and (Master and $\mathrm{PhD}$ ) consumers' education levels in favour of (Master and $\mathrm{PhD}$ ) consumers' education levels.

Table 6. Scheffe' test results (weekly expenditure)

\begin{tabular}{ccccc}
\hline \multirow{2}{*}{ Weekly expenditure in the malls (JD) } & 50 and less & $51-100$ & $101-150$ & More than 150 \\
\cline { 2 - 5 } & Means & 3.97 & 4.07 & 4.13 \\
\hline 50 and less & 3.97 & & & \\
JD 50 - 100 & 4.07 & $* 0.24$ & & \\
JD101-150 & 4.13 & $* 0.29$ & 0.06 & 0.01 \\
More than JD 150 & 4.22 & $* 0.31$ & 0.07 & \\
\hline
\end{tabular}

Note. * Significant at $(\propto=0.05)$.

Table 6 shows, that there are significant differences between the means of (Less 50 JD and less, and JD 51-100) and (JD101-150 and more than JD 150) in favor of (50 JD Less than, and JD 51-100) weekly expenditure in the malls.

\section{Discussion and Conclusions}

The study shows the importance of the presence of entertainment activities in the Jordanian malls. The presence 
of leisure facilities gives more excitement and fun for shoppers to increase their desire to stay longer in the mall. This finding supports the findings of Wakefield and Baker (1998) and Anuradha and Manohar (2011).

Another finding in the study is that the presence of places and entertainment facilities in malls motivates and encourages shoppers to visit the shopping mall and thus achieves satisfaction. For instance, cinemas, theatres, gym, as well as the existence of kids' entertainment are examples of places and entertainment facilities in malls. This finding is in line with the results of a study conducted by El-Adly (2007) and Ozsoy (2010).

The results reveal that entertainment is a key factor in the malls where it leads to frequencies of shoppers' visits, break the daily routine of their life, and reduce their nervous tension. This finding supports the findings of Bloch et al. (1994) and El-Adly (2007) in that malls are viewed by consumers as a place, not only for shopping, but also for other activities, such as entertainment. It also supports the viewpoint of Sit et al. (2003) that entertainment deserves to be a distinct factor that comprises multiple items rather than a single item.

Mall management should aspire to make shoppers comfortable in their shopping as it is important to have huge entertainment facilities in light of the fact that many shoppers are looking for entertainment. In the same context, mall managers have to create a pleasant environment for shopping if they want shoppers to visit their shopping malls more frequently and spend more time in the malls. This can be accomplished by having family entertainment centers, cinema, gym, bowling alley, billiard hall and video games.

\section{Limitations and Future Research}

Although this study could be seen as an initial attempt to understand the shoppers' entertainment at famous malls in one of the biggest city in Jordan, but it is important to acknowledge its limitations. First, the data collection covers only the city town and drive only from the five biggest malls. Second, how to be sure that the shoppers actually behave as they claim.

Therefore, given these limitations, there are some promising for future studies about the market area not covered, motivational dimensions of special entertainment events, the influence of cultural factors on shopping behavior locally and internationally, and the factors that affect the preference of shoppers and attract them to shopping malls.

\section{References}

Ahmed, Z. U., Morry, G., \& Zainurin, D. (2007). Malaysian shopping mall behaviour: An exploratory study. Asia Pacific Journal of Marketing and Logistics, 19(4), 331-348. http://dx.doi.org/10.1108/13555850710827841

Al-khateeb, F. S. (2009). Factors influencing malls selection from Jordanian customers point of view. Jordan Journal of Business, 5(1).

Andersen, C. H. (2003). EMAAR announces 'Dubai Mall' the world's largest shopping centre. Retrieved from http://www.ameinfo.com/31239.html

Andersen, C. H. (2005). The Dubai mall brochure collects three awards at summit creative awards 2005. Retrieved from http://www.ameinfo.com/60865.html

Anuradha, D., \& Manohar, H. L. (2011). Customer shopping experience in malls with entertainment centres in Chennai. African Journal of Business Management, 5(31), 12319-12324. http://dx.doi.org/10.5897/AJBM11.902

Bellenger, D., Robertson, D., \& Greenberg, B. (1977). Shopping centre patronage motives. Journal of Retailing, 53(2), 29-38.

Bloch, P. M., Ridgway, N. M., \& Dawson, S. A. (1994). The shopping mall as consumer habitat. Journal of Retailing, 70(1), 23-42. http://dx.doi.org/10.1016/0022-4359(94)90026-4

Bodkin, C., \& Lord, J. (1997). Attraction of power shopping centres. The International Review of Retail, Distribution \& Consumer Research, 7(2), 93-108. http://dx.doi.org/10.1080/095939697343058

Darden, W. R., \& Zikmund, W. G. (2000). Business research methods (6th ed.). Dryden.

Dennis, C., Marsland, D., \& Cockett, T. (2001). The mystery of consumer behaviour: Market segmentation and shoppers' choices of shopping centres. International Journal of New Product Development and Innovation Management, 3(3), 221-237.

El-Adly, M. I. (2001). Segmenting food shoppers in the United Arab Emirates according to their attitudes towards food shopping. Journal of Economic \& Administrative Sciences, 17, 36-69. 
El-Adly, M. I. (2007). Shopping malls attractiveness: A segmentation approach. International Journal of Retail Distribution Management, 35(11), 936-950. http://dx.doi.org/10.1108/09590550710828245

Finn, A., \& Louviere, J. (1996). Shopping centre image, consideration, and choice: Anchor store contribution. Journal of Business Research, 21(November), 259-275.

Frasquet, M., Gil, I., \& Molla, A. (2001). Shopping-centre selection modeling: A segmentation approach. International Review of Retail, Distribution and Consumer Research, 11(1), 23-38. http://dx.doi.org/10.1080/09593960122279

Frat, A. F., \& Venkatesh, A. (1993). Post-modernity: The age of marketing. International Journal of Research in Marketing, 10(3), 227-249. http://dx.doi.org/10.1016/0167-8116(93)90009-N

Groover, J. (2005). U.S. looks abroad for latest shopping centre innovations. Retrieved April 22, 2005 from http://www.icsc/org/srch/sct/sct0305/index.php?region=

Haytko, L. D., \& Baker, J. (2004). It's all at the mall: Exploring adolescent girls. Journal of Retailing, 80(1), 67-83. http://dx.doi.org/10.1016/j.jretai.2004.01.005

Hunter, G. L. (2006). The role of anticipated emotion, desire, and intention in the relationship between image and shopping centre visits. International Journal of Retail \& Distribution Management, 34(10), 709-721. http://dx.doi.org/10.1108/09590550610691310

Kim, I., Christiansen, T., Feinberg, R., \& Choi, H. (2005). Mall entertainment and shopping behaviors: A graphical modeling approach. Advances in Consumer Research, 32(1), 487-492.

Kim, Y. K., Kim, E. Y., \& Kang, J. (2003). Teens' mall shopping motivations: Functions of loneliness and media usage. Family and Consumer Sciences Research Journal, 32(2), 140-167. http://dx.doi.org/10.1177/1077727X03032002004

LeHew, M. L. A., Burgess, B., \& Wesley, S. (2002). Expanding the loyalty concept to include preference for a shopping mall. International Review of Retail, Distribution and Consumer Research, 12(3), 225-236. http://dx.doi.org/10.1080/09593960210139643

Levy, M., \& Weitz, B. A. (2004). Retailing management (5th ed.). Boston: Mc Graw Hill/ Irwin.

Michon, R., \& Chebat, J. C. (2004). Cross-cultural mall shopping values and habitats: A comparison between english and french-speaking Canadians. Journal of Business Research, 57(8), 883-892. http://dx.doi.org/10.1016/S0148-2963(02)00291-6

Ng, C. F. (2003). Satisfying shoppers' psychological needs: From public market to cyber-mall. Journal of Environmental Psychology, 23, 439-455. http://dx.doi.org/10.1016/S0272-4944(02)00102-0

Nicholls, J. A. F., Li, F., Kranendonk, C. J., \& Roslow, S. (2002). The seven year itch? Mall shoppers across time. Journal of Consumer Marketing, 19(2), 149-165. http://dx.doi.org/10.1108/07363760210420568

Nicholls, J. A. F., Li, F., Mandokovic, T., Roslow, S., \& Kranendonk, C. (2000). US-Chilean mirrors: Shoppers in two countries. Journal of Consumer Marketing, 17, 106-119. http://dx.doi.org/10.1108/07363760010317187

Özsoy, M. (2010). User preferences on transformations of shopping centres into private urban public spaces: The case of Izmir, Turkey. African Journal of Business Management, 4(10), 1990-2005.

Parsons, A. G. (2003). Assessing the effectiveness of shopping mall promotions: Customer analysis. International Journal of Retail \& Distribution Management, $31(2), \quad 74-79$. http://dx.doi.org/10.1108/09590550310461976

Pine, J., \& James, G. (1999). The experience economy. Boston, Mass: Harvard Business School Press.

Pride, W. M., \& Ferrel, O. C. (1983). Marketing basic concepts and decisions. Boston: Houghton Mifflin Company.

Reimers, V., \& Clulow, V. (2009). Retail centers: It's time to make them convenient. International Journal of Retail Distribution Management, 37(7), 541-562. http://dx.doi.org/10.1108/09590550910964594

Ruiz, F. (1999). Image of suburban shopping malls and two-stage versus uni- equational modelling of the retail trade attraction: An empirical application. European Journal of Marketing, 33(5/6), 512-530. http://dx.doi.org/10.1108/03090569910262071

Sekaran, U., \& Bougie, R. (2013). Research methods for business: A skill building approach (6th ed.). Wiley. 
Sheth, J. (1983). An integrative theory of patronage preference and behavior. In W. R. Darden, \& R. F. Lusch (Eds.), Patronage behavior and retail management (pp. 9-28). New York: North-Holland.

Sit, J., Merrilees, B., \& Birch, D. (2003). Entertainment-seeking shopping centre patrons: The missing segments. International Journal of Retail\& Distribution Management, 31(2), 80-94. http://dx.doi.org/10.1108/09590550310461985

Smith, J. (2003). Shoppers' changing needs are redefining retail. Inside Retailing, 14-15.

Taylor, S. L., \& Cosenza, R. M. (2002). Profiling later aged female teens: Mall shopping behavior and clothing choice. Journal of Consumer Marketing, 19(5), 393-408. http://dx.doi.org/10.1108/07363760210437623

Terblanche, N. S. (1999). The perceived benefits derived from visits to a super-regional shopping centre: An exploratory study. South African Journal of Business Management, 30(4), 141-146.

Underhill, P. (1999). Why we buy? The Science of Shopping, Simon Schuster, New York, NY.

Wakefield, K. L., \& Baker, J. (1998). Excitement at the mall: Determinants and effects on shopping response. Journal of Retailing, 74(4), 515-539. http://dx.doi.org/10.1016/S0022-4359(99)80106-7

Wong, G., Yu, L., \& Yuan, L. (2001). SCATTR: An instrument for measuring shopping centre attractiveness. International Journal of Retail \& Distribution Management, 29(2), 76-86. http://dx.doi.org/10.1108/09590550110381535

\section{Copyrights}

Copyright for this article is retained by the author(s), with first publication rights granted to the journal.

This is an open-access article distributed under the terms and conditions of the Creative Commons Attribution license (http://creativecommons.org/licenses/by/3.0/). 